\title{
The treatment of facial asymmetry: Review
}

\author{
Kazimierz Kobus ${ }^{1, A, C-F}$, Katarzyna Kobus-Zaleśna ${ }^{2, A-C}$ \\ ${ }^{1}$ Department and Clinic of Plastic Surgery in Polanica-Zdrój, Wroclaw Medical University, Poland \\ ${ }^{2}$ Department of the Maxillary Orthopaedics and Orthodontics, Autonomous Centre for Facial Developmental Defects, Wroclaw Medical University, Poland \\ A - research concept and design; $\mathrm{B}$ - collection and/or assembly of data; $\mathrm{C}$ - data analysis and interpretation; \\ $\mathrm{D}$ - writing the article; $\mathrm{E}$ - critical revision of the article; $\mathrm{F}$ - final approval of the article
}

\section{Address for correspondence \\ Katarzyna Kobus-Zaleśna}

E-mail:ortodoncja@kobus-zalesna.pl

\section{Funding sources}

None declared

\section{Conflict of interest}

None declared

\section{Acknowledgements}

Figures, with the exception of Fig. 4 and 6 , were used with the permission of the publisher.

Received on December 5, 2015

Reviewed on October 29, 2016

Accepted on February 14, 2017

\begin{abstract}
Some degree of congenital or acquired asymmetry is normal and universal. Significant facial asymmetry, however, causes both aesthetic, as well as functional problems. The comprehensive management of facial symmetry is scarcely addressed. ${ }^{1-5}$ Differing etiologies, heterogeneous material, and different ages of patients tend to produce fragmentary reports, the more so as evidence-based evaluation of outcomes is almost impossible. Therefore, a presentation of the general rules of treatment, illustrated by our own material collected from the Hospital and Clinic of Plastic Surgery in Polanica-Zdrój and from private surgical and orthodontic practice, could be regarded as useful and justified. Special attention has been given to both functional and cosmetic problems encountered in severe congenital and acquired asymmetries. The management of selected craniofacial malformations in so-called rare clefts, cleft lip and palate, and craniofacial microsomia (CFM), as well as large hemangiomas and neurofibromas, have been discussed. Additionally, the treatment of extensive and asymmetrical post-traumatic deformities and defects is discussed with particular attention given to problems related to ankylosis of the temporomandibular joints. Numerous examples of one-stage procedures, as well as combined, multidisciplinary treatments are presented.
\end{abstract}

Key words: trauma, congenital malformations, facial asymmetry, surgical and orthodontic treatment, tumors

DOI

$10.17219 /$ acem/68976

\section{Copyright}

Copyright by Author(s)

This is an article distributed under the terms of the

Creative Commons Attribution Non-Commercial License

(http://creativecommons.org/licenses/by-nc-nd/4.0/) 


\section{Introduction}

Symmetry is one of the key elements, which affects the sense of esthetics and identifies the standards of beauty. In architecture and the arts, it usually evokes a feeling of order, proportion, and elegance. The classical Greek Parthenon or the Vitruvian Man are invariably associated with perfection and beauty, although, paradoxically, it is still pleasant to look at the asymmetric Sagrada Família or Picasso's Self-Portrait.

In the animal world, good proportions and symmetry indirectly demonstrate health, strength, and the chances of favourable reproduction. In humans, it has an impact on relationships, better quality of life, and higher social status. Thus, deer with impressive antlers are not only the source of jokes and a symbol of infidelity, but also an allegory of strength, attractiveness, and beauty.

Perfection may be a pattern, but should not be considered the norm, because finding yourself below a certain threshold would be depressing and difficult to imagine. Moreover, it is worth remembering that the length of the upper limbs of the famous statue of David are not equal, and that the halves of the Mona Lisa's face are not balanced. Despite this, both masterpieces are considered to be beautiful, which proves that certain disorders and imperfections in symmetry are acceptable and even beneficial. Therefore, the problem is in their structure and intensity. Acceptance of this assumption alleviates the perception of asymmetry. However, it only slightly affects the feelings of the affected persons, which results from both social reactions and a level of personal acceptance. Apart from an actual or simulated perception of imperfect beauty, it happens that even small deviations from the standard appearance grow into difficult-tosolve problems. The effectiveness of the most sophisticated therapies and psychotherapeutic programmes usually ends where contact with a society devoid of empathy begins.

In some cases, facial asymmetry is accompanied by more or less severe malfunctions, such as impairment of feeding or respiratory disorders, which create additional problems and require multidisciplinary treatment. Regardless of etiology, problems associated with the restoration of the proper functioning and appearance of the face are often extremely difficult due to the frequent coexistence of abnormalities in the bone, dental and soft tissues. $^{1-5}$

The effectiveness of treatment depends on many factors, such as a deficiency or excess of tissues, a disorder, or a lack of reference to normal anatomical structures, and the inability to completely correct multiple irregularities. Significant factors also tend to be associated with the patients' age and health problems, which arise from the coexistence of multiple disorders or injuries, as well as from (often inevitable) multi-staged and longlasting treatment. Additional factors can be related to financial problems and a limited number of centres performing highly specialised and sometimes risky operations.

\section{Principles of treatment}

The pursuit of simultaneous and compound correction is obvious indeed, but it is not always possible. In most occlusal asymmetries - related mostly to the lower part of the face and maxillary retrusion - there is a need for preoperative orthodontic treatment which, in patients treated with distraction osteogenesis, must be long-lasting and conducted in stages. ${ }^{6-8,11}$ The latter involves the selection of the proper sequence of treatment and preferred correction of the skeleton before or at the same time as the repair of soft tissues. Due to various forms of asymmetry, particular attention is paid to the proper and individual selection of methods used in craniofacial, maxillofacial, or reconstructive plastic surgery (Fig. 1).

In patients with coexisting soft tissue deficiency, the restoration and modelling of facial contours can be achieved with the use of autologous fat transfer, dermal grafts, local flaps, and free flap transplantation. Despite an increased trend to replace soft tissue volume by autologous fat transfer, the lipofilling can only satisfy the requirements of minor asymmetries. The main problem lies in the unpredictability of fat resorption and the need for revisionary procedures. ${ }^{12,13}$ As an alternative, the use of dermal grafts is more highly recommended, and the outcomes are seemingly more predictable.

The utility of local flaps is rather moderate due to their limited size and secondary deformities, although in some cases the use of tongue flaps for lip repair or galea flaps for the restoration of moderate hemifacial progressive atrophy can be taken into consideration.

In severe cases, for more than 30 years, the preferred method of soft tissue restoration has been microsurgical tissue transplantation. ${ }^{14,15}$ Buried skin and musculocutaneous flaps are considered to be the most effective and reliable material, applied separately or in combination with other methods. ${ }^{16-19}$

Nowadays, the planning of surgical procedures is greatly simplified due to precise radiological measurements and the use of computer simulation. This is particularly important in complex deformities, including both the neuro- and the viscerocranium, where finding corresponding normal anatomical structures happens to be very difficult. For the correction of occlusal disorders, the classic cephalometry and analysis of dental models still play an essential role in planning. ${ }^{20,21}$

The age of patients is of great importance in the treatment of premature cranial synostosis and clefts. Asymmetry resulting from unilateral coronal and lambdoid synostosis also applies to the opposite, healthy side of the skull. These deformations are of a compensatory nature, 
Fig. 1. Facial asymmetry before (A) and after multiple osteotomy followed by dermal grafting (B)

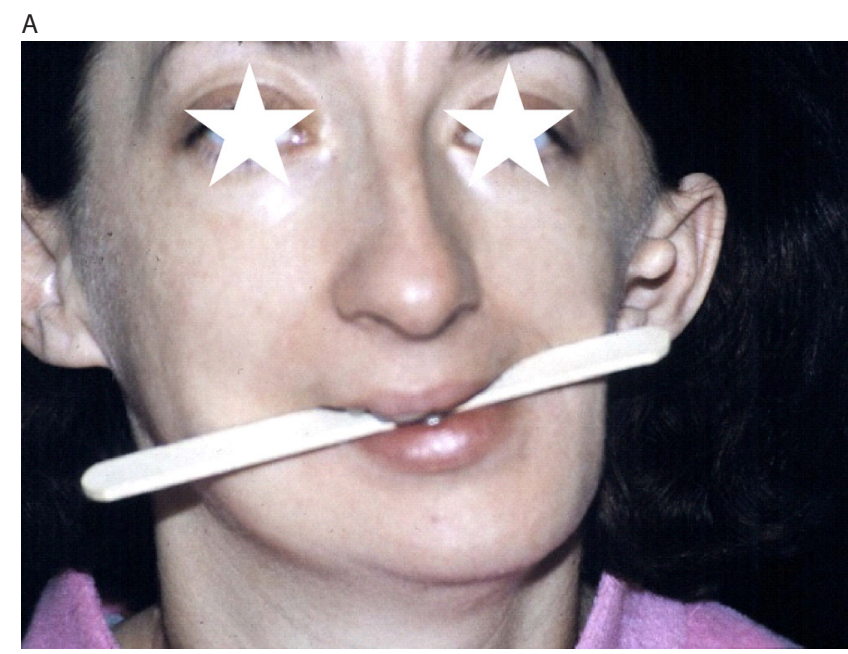

B

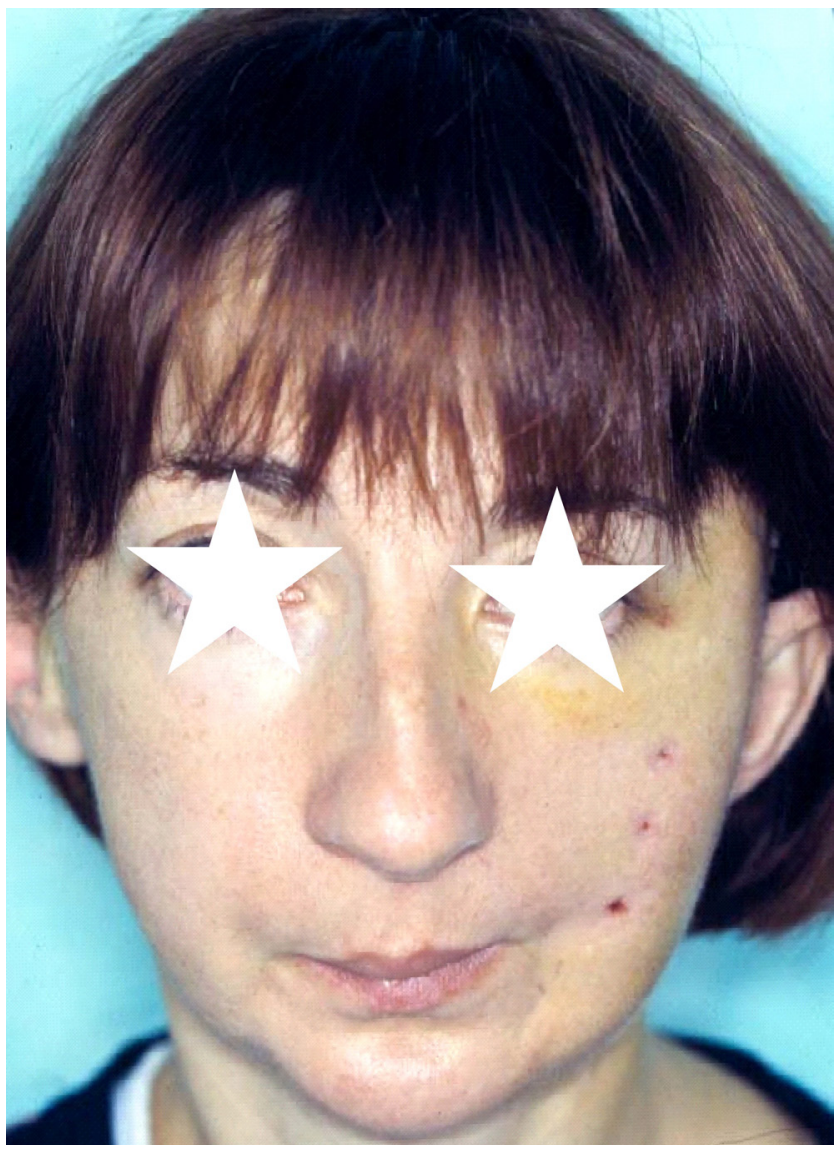

From: Kobus K. Atlas chirurgii plastycznej. Warszawa: Medsportpress; 2004 and Kobus K. Chirurgia i estetyka twarzy, Wrocław: ArsMedica, 2014

caused by the brain growing in the directions of least resistance. Thus, contrary to the definition, shape disorders are not one-sided only and, due to their complexity, they are difficult to correct. ${ }^{22-24}$

In young children after resection of synostosed cranial sutures and modelling of the forehead and orbital roofs, the released, expanding brain enhances the cranial vault shaping. After a few years the cranium and upper third of the face look normal, as a rule (Fig. 2).
Fig. 2. A 3-month-old child with plagiocephaly. Cranial deformation with orbital dystopia before (A) and after operation (B)

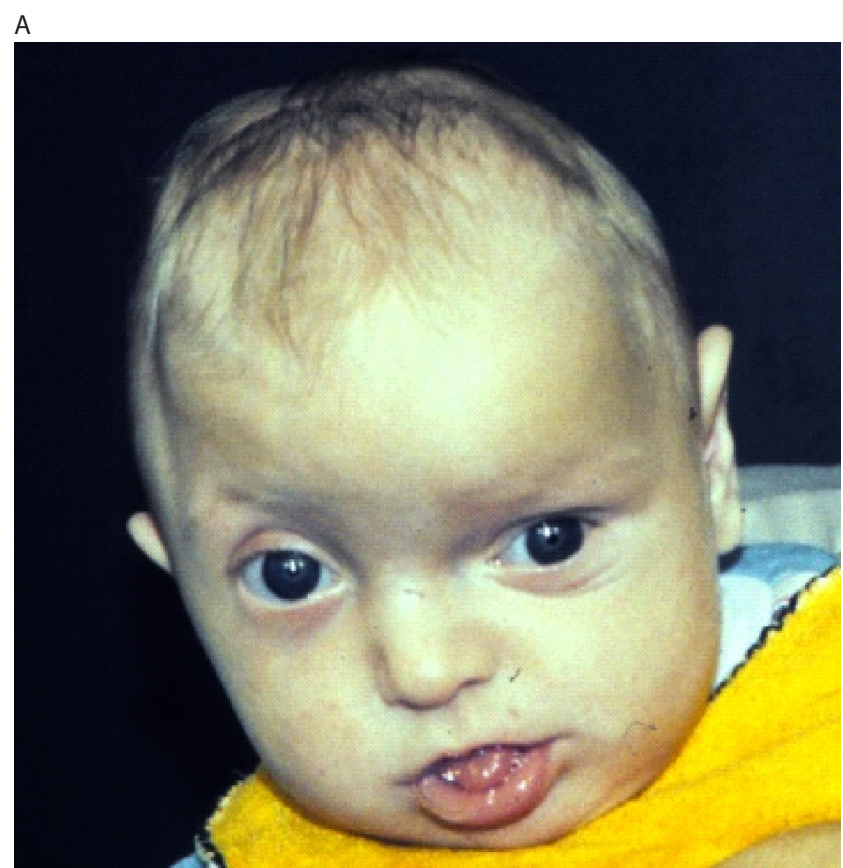

B

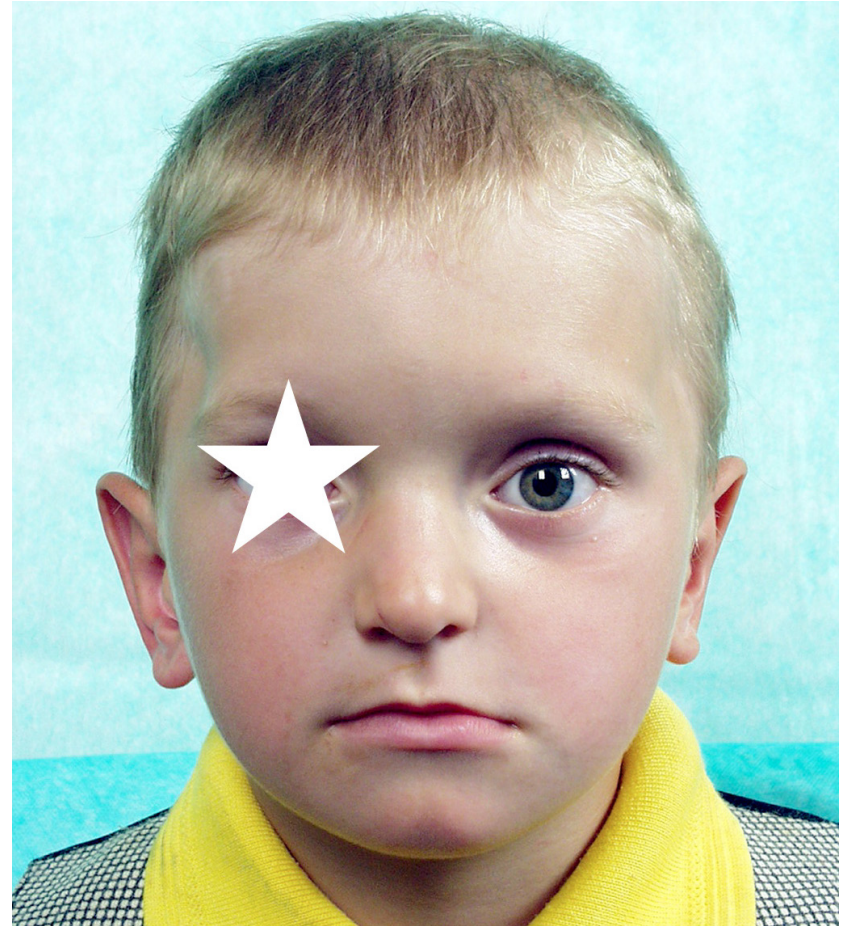

From: Kobus K. Atlas chirurgii plastycznej. Warszawa: Medsportpress; 2004 and Kobus K. Chirurgia i estetyka twarzy, Wrocław: ArsMedica, 2014.

After a slowdown in the growth process and a reduction in brain growth potential, the phenomenon of selfcorrection is less evident. Accordingly, in older patients, despite the need for a much more extensive surgery, the results of treatment are usually worse.

In other craniostenoses, the asymmetry is less severe and, if observed, it concerns the obliteration of multiple cranial sutures and cases with concomitant hydrocephalus or rare clefts. ${ }^{25,26}$ 
Fig. 3. Unilateral cleft lip and palate before (A) and early result of treatment - note the nose deviation (B); final outcome after bony platform restoration and rhinoplasty (C)

A

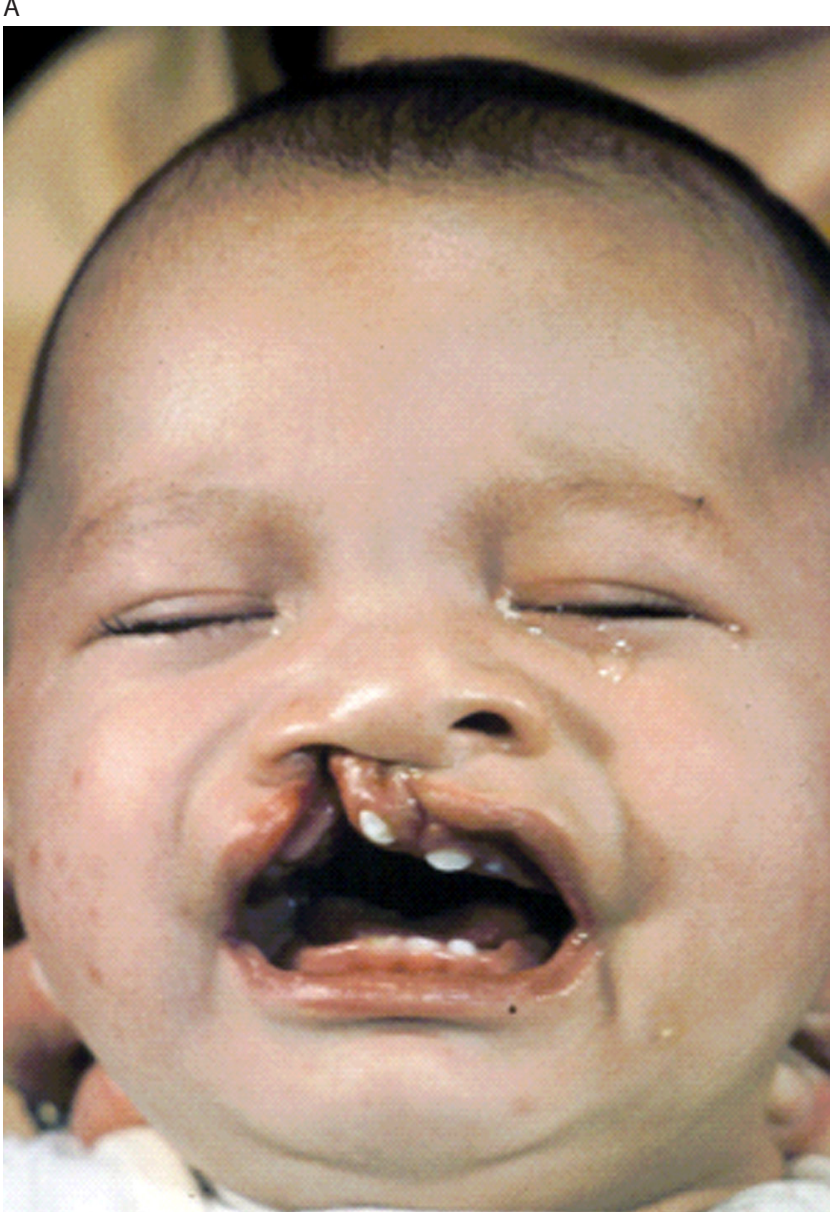

B

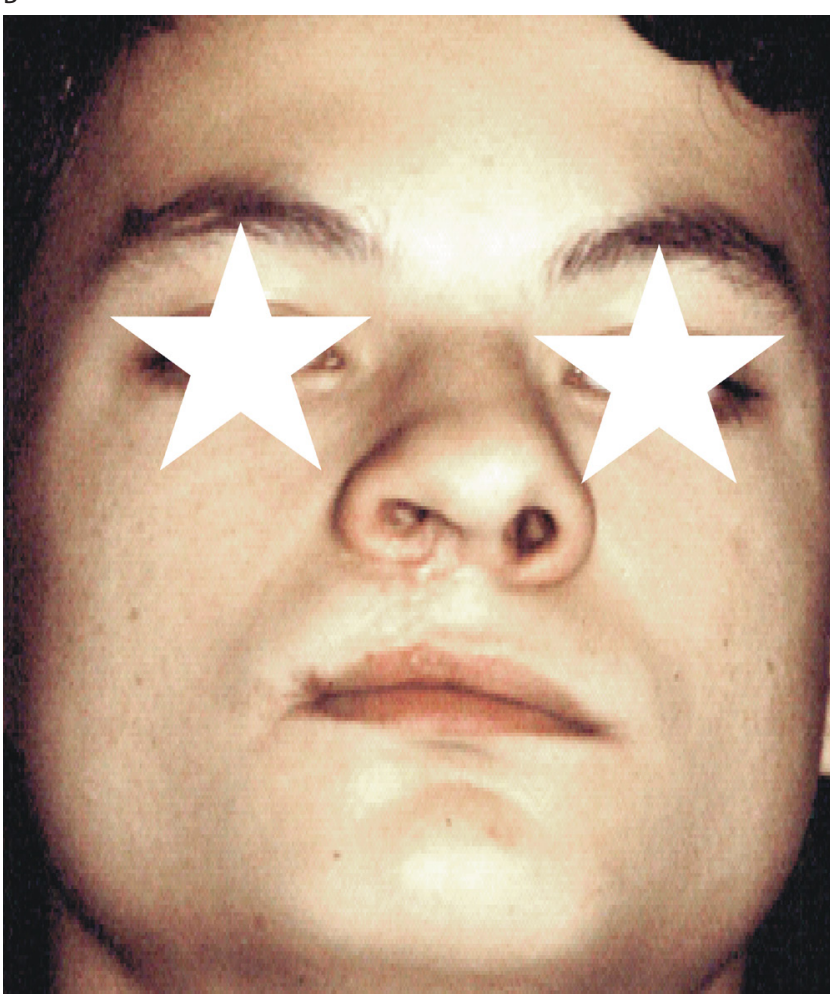

Unlike craniostenosis, the optimal age for repair of cleft lip and cleft palate is not explicitly defined, and raises a lot of controversy. According to a rather common belief, early operations are beneficial for speech development, but are less favourable for midface development. Moreover, with the passage of time, an impaired growth potential has a tendency towards aggravation. ${ }^{27-29}$

Symmetry disorders do not affect only unilateral clefts because in bilateral forms an unequal severity of defects is often encountered. In total clefts, the most significant issues are the malposition of maxillary segments and the lack of so-called bone platform, which induce septum and nose deviation. So, after a complete cleft lip repair, which is usually performed at the age of 3-6 months, some gradual deterioration of appearance is usually noted, particularly if unsatisfactory maxillary development occurs.

An almost routine procedure performed in the period of mixed dentition, between the ages of 7 and 11 years, is alveolar bone grafting with subsequent orthodontic treatment, and the use of fixed appliances. According to our own observations and other reports, restoration of continuity and alveolar arch formation should always precede possible jaw osteotomy and final lip and nose corrections (Fig. 3). ${ }^{27,30}$

In contrast to the above-mentioned malformations, correction of asymmetry in Parry-Romberg syndrome is performed much later, after the cessation or slowing down of tissue atrophy, which usually occurs after puberty (Fig. 4). Soft tissue corrections are usually carried out with the use of musculocutaneous free flaps, although previous bone repair is more logical. Due to the

C

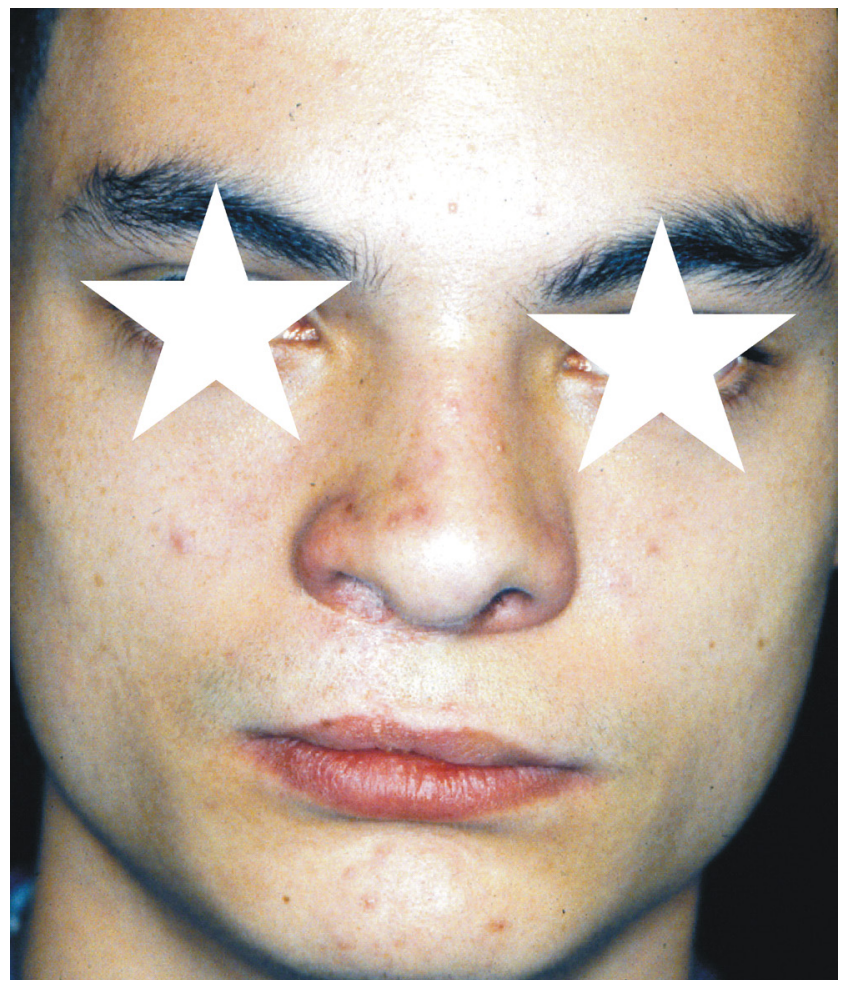


Fig. 4. Aggravation of bone and soft tissue hypoplasia in Parry-Romberg syndrome (photos taken at the ages of 6, 9 and 15 years)
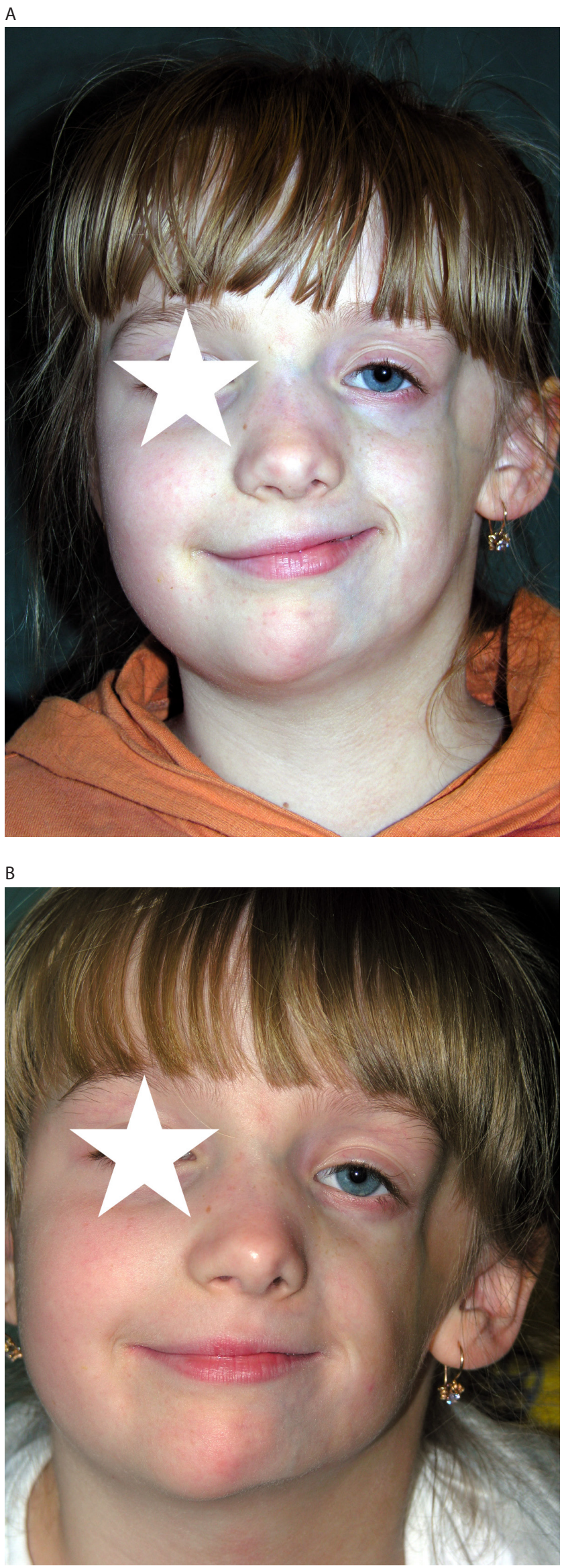

poor quality of tissues, classic bi-jaw osteotomy is rather risky; therefore, a safer distraction osteogenesis according to the McCarthy and Ortiz-Monasterio and Molina methods seems to be more recommendable. ${ }^{5,8,10,14}$

The treatment of facial asymmetries caused by proliferative lesions, such as haemangiomas, neurofibromas, and fibrous bone dysplasia, should possibly be performed in their early stages. Correction of advanced forms of above mentioned lesions is very difficult, and in particular it applies to deforming, life-threatening hemangiomas, whose resection is extremely difficult and risky. ${ }^{31-33}$ In most severe cases, despite superselective embolisation followed by immediate resection, complete eradication turns out to be incomplete. Postoperative mutilations, such as total or partial facial nerve paralysis or large defects and deformities, can be very distressing.

In neurofibromas, there are significant problems connected with maxillary disorders, orbital wall destruction and optic nerve infiltration, while in fibrous dysplasia, correction of jaw deformities and the oft-encountered malposition and reduction of the orbital volume is a real challenge. Since the eradication of pathological lesions in such cases is rarely possible, surgical intervention is often of a palliative and temporary nature (Fig. 5).

The severity of congenital asymmetries caused by tissue deficiency varies greatly. Although evident in complete clefts and Parry-Romberg syndrome, a more striking deficit, especially of bone, is referred to as hemifacial microsomia (HFM). This condition, also known as craniofacial microsomia (CFM), is characterised by unilateral or - in $10 \%$ of cases - bilateral deficiency of bone and soft tissues. ${ }^{34}$

C

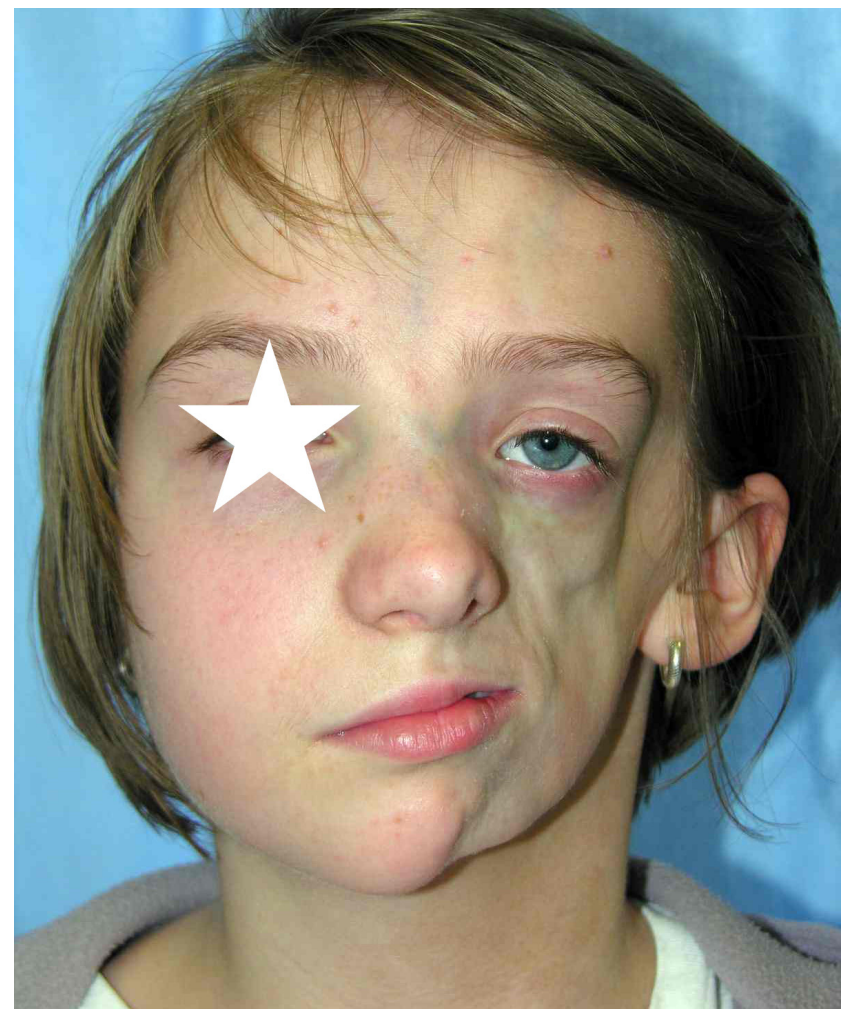


Fig. 5. Neurofibroma (A) and 3D TK before treatment (B); patient's appearance after 3 operations (C, D)
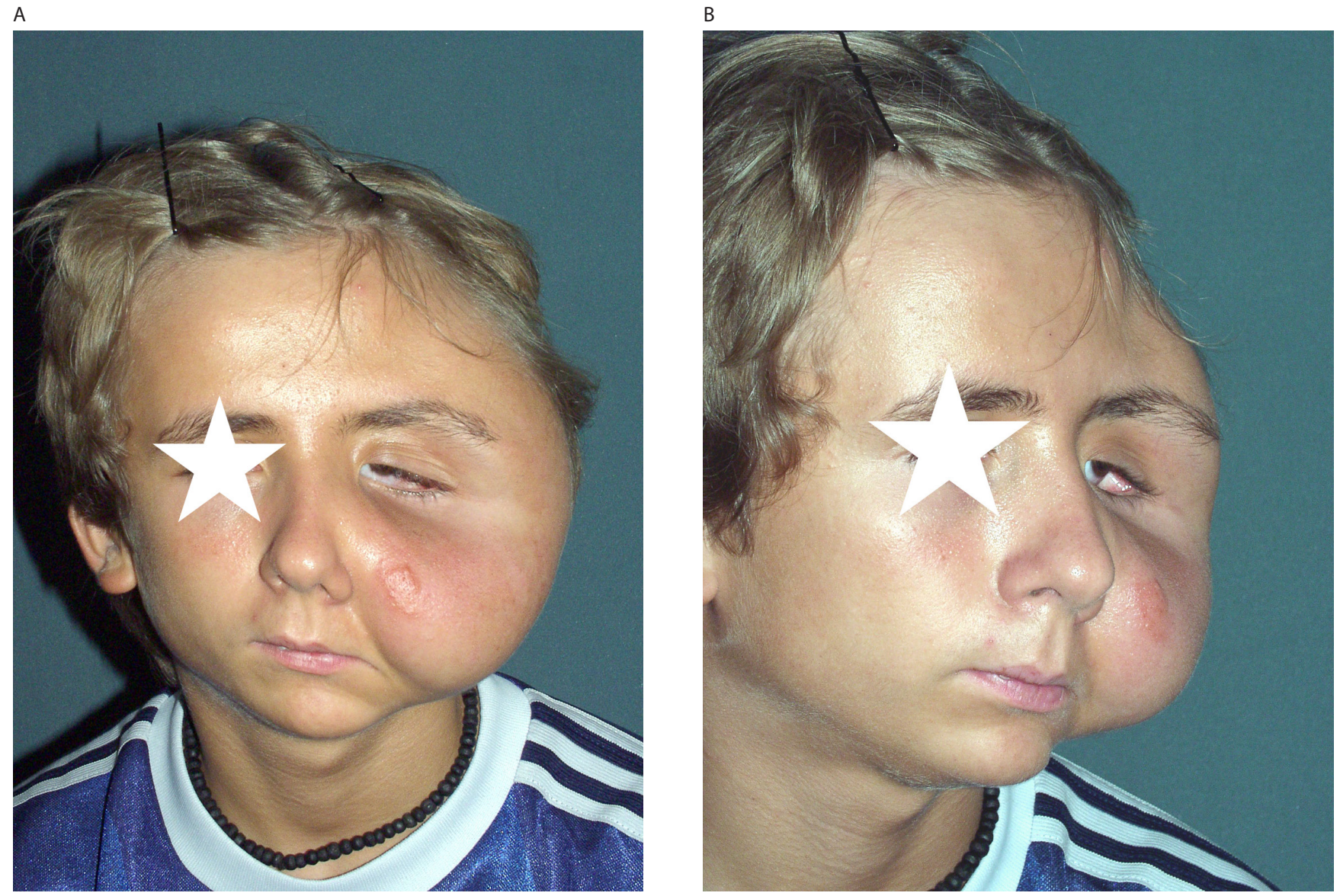

C

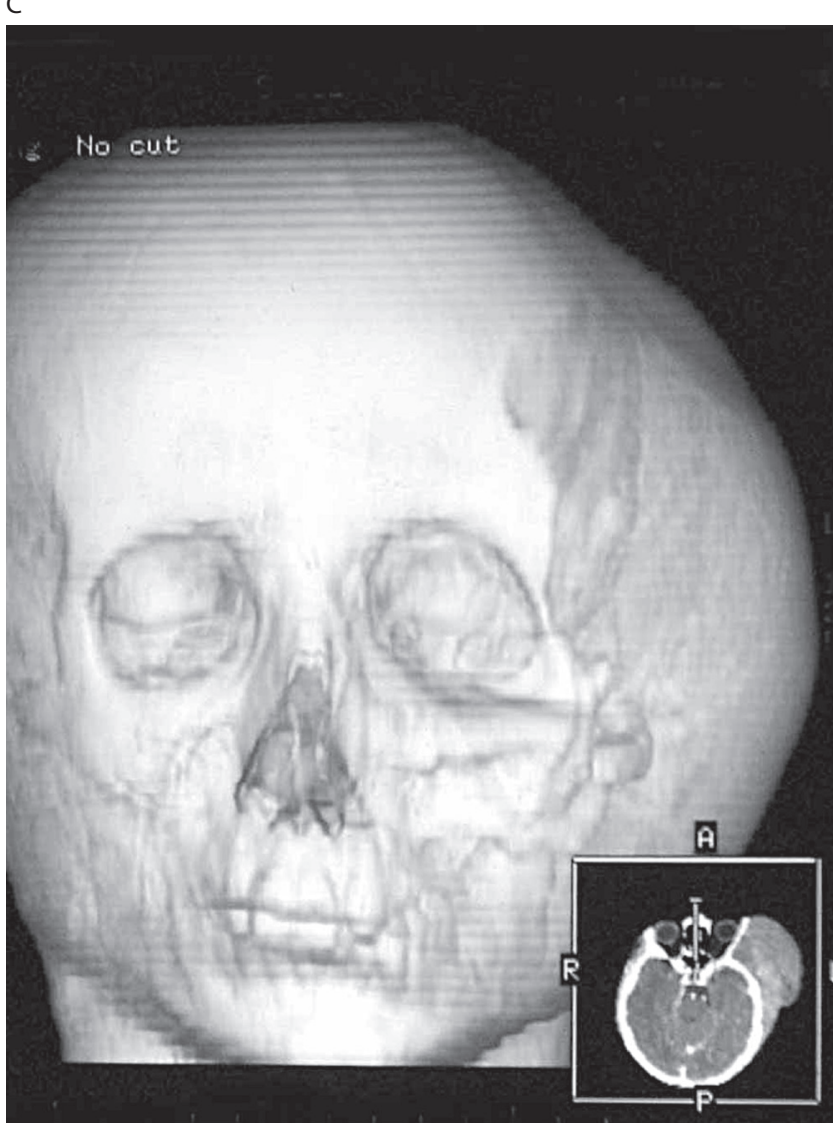

D

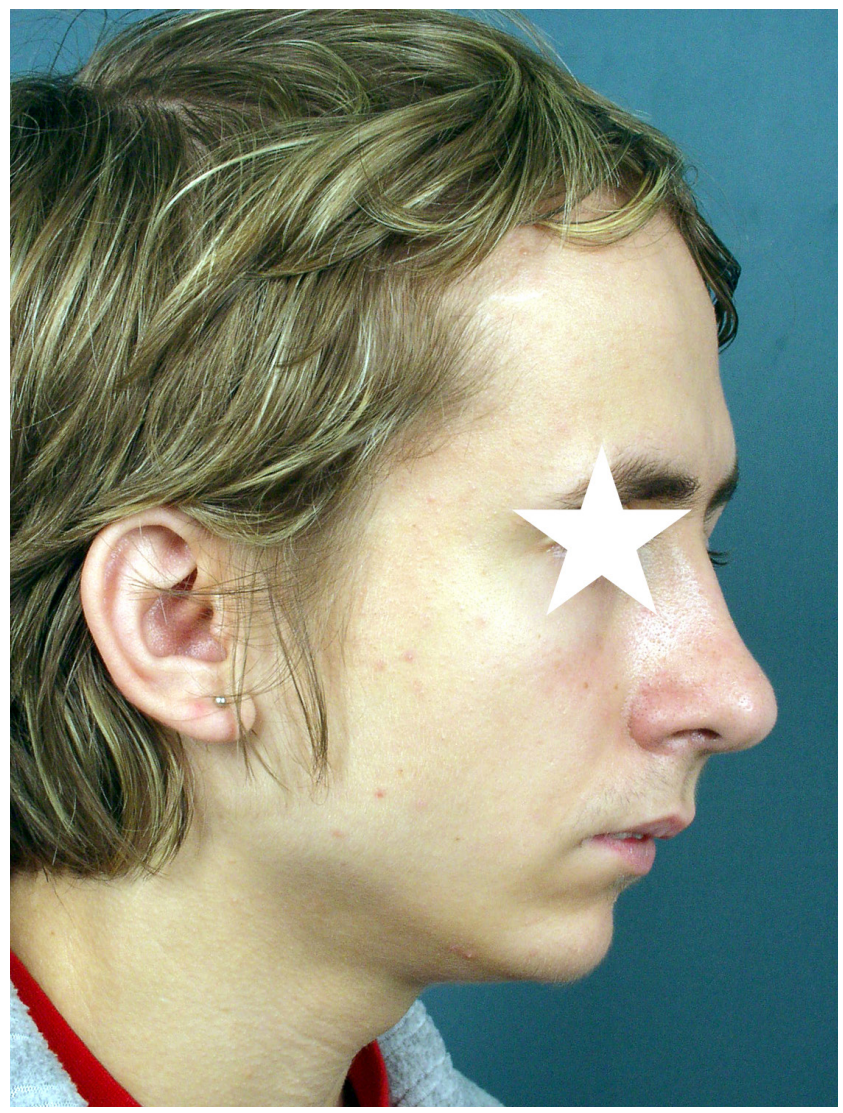

From: Kobus K. Atlas chirurgii plastycznej. Warszawa: Medsportpress; 2004 and Kobus K. Chirurgia i estetyka twarzy, Wrocław: ArsMedica, 2014. 
Hypoplasia of the mandibular ramus and temporomandibular joint (TMJ), which is the basis of its classification, define the treatment possibilities depending mostly on bone stock deficiency. ${ }^{35,36}$

In Type I and partially in Type II of Kaban's classification, distraction osteogenesis - introduced in 1992 by McCarthy et al. - is the treatment of choice. Elongation of the mandibular ramus and assisted orthodontic alignment of the occlusal plane is so effective that an existing soft tissue deficiency is usually less perceptible. , $^{8,36}$

In moderate cases, there is often a need for bone augmentation, while in severe forms reconstruction of the zygomatic arch, TMJ, and mandibular ramus are unavoidable. ${ }^{14,37,38}$ Due to narrowing of the affected side of the face, in some patients the osteochondral rib grafts must be located behind the hypoplastic ear. In such cases, despite reconstruction of the mandibular arch and a satisfactory occlusal plane setting, a symmetrical skeleton is rather impossible to obtain. However, as a significant hypoplasia of the soft tissues makes repeated dermal grafting or free flap transplantation necessary, some camouflage of the bone imperfections is as well achieved.

With time, the reconstructed mandibular parts grow thicker, and in some cases they get become too long, leading to contralateral recurrence of asymmetry, which resembles laterogenia, and requires reduction osteotomies (Fig. 6). ${ }^{37}$

Fig. 5. (cont.)

E

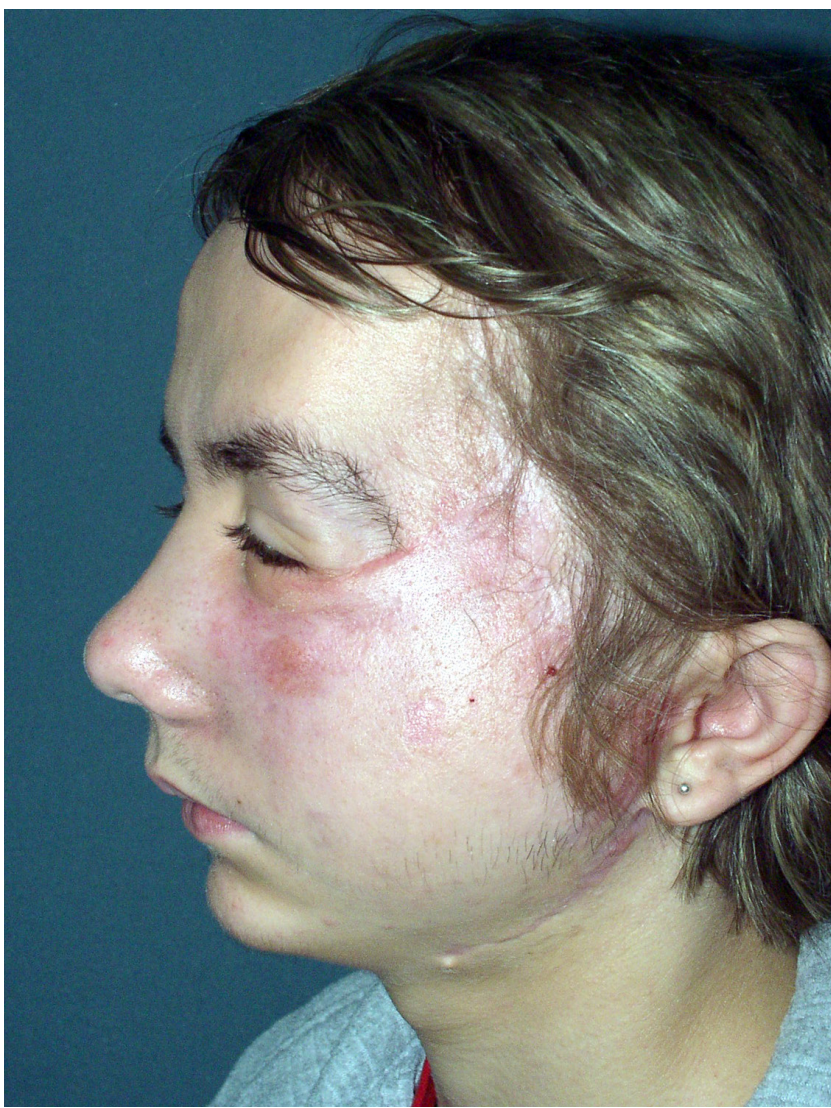

Fig. 6. Severe hemifacial microsomia before (A) and after mandibular ramus reconstruction with costochondral rib graft (B); $X$-ray taken after shortening of the newly created overgrowing ramus due to its excessive elongation (C)

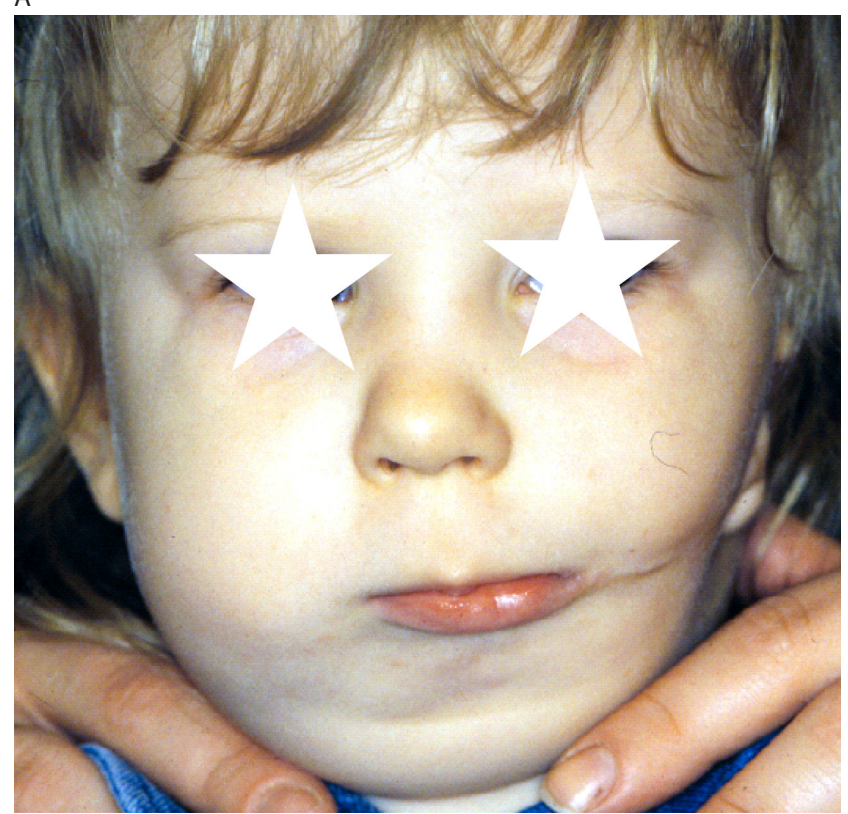

B
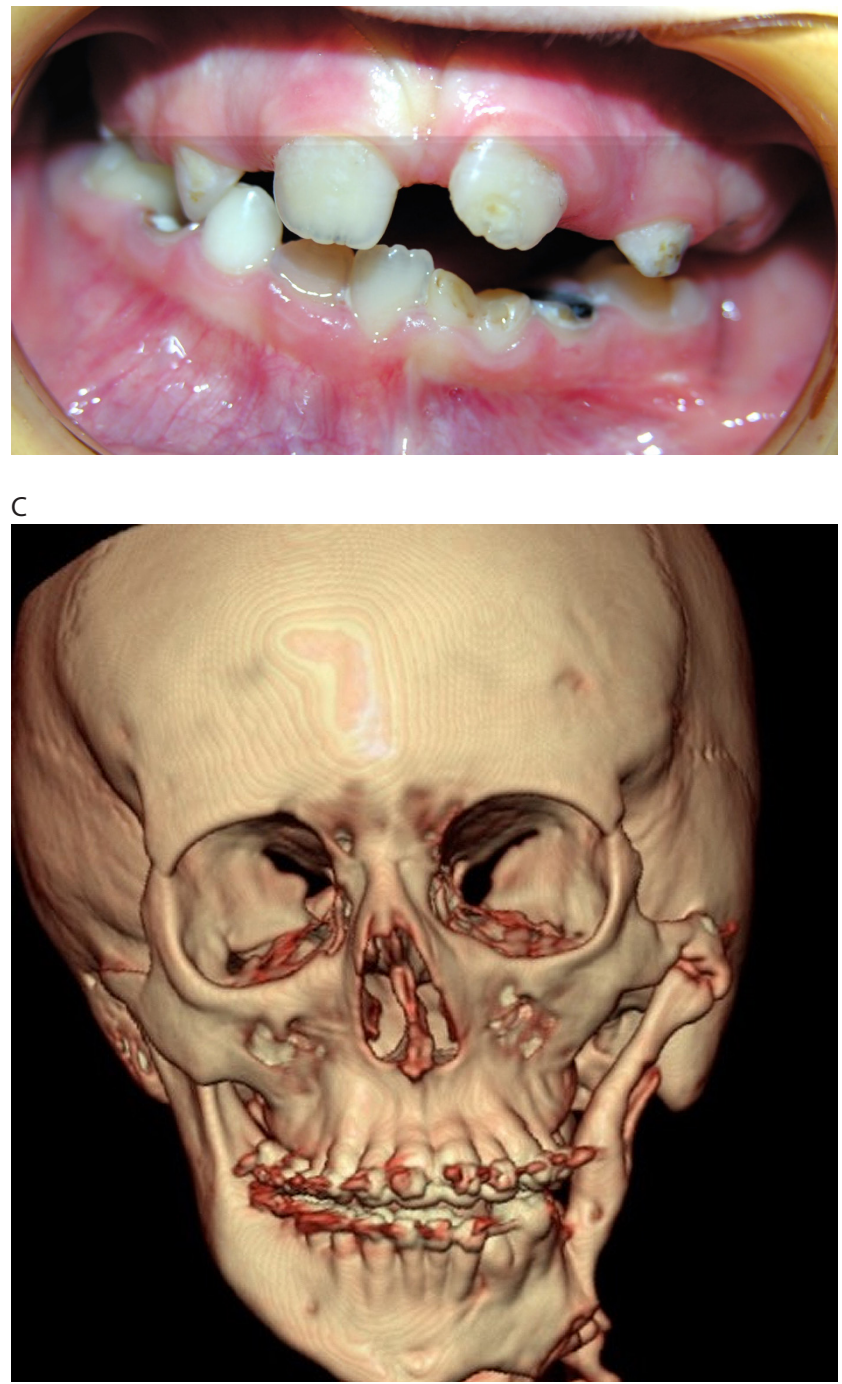
Fig. 6. (cont.)

D

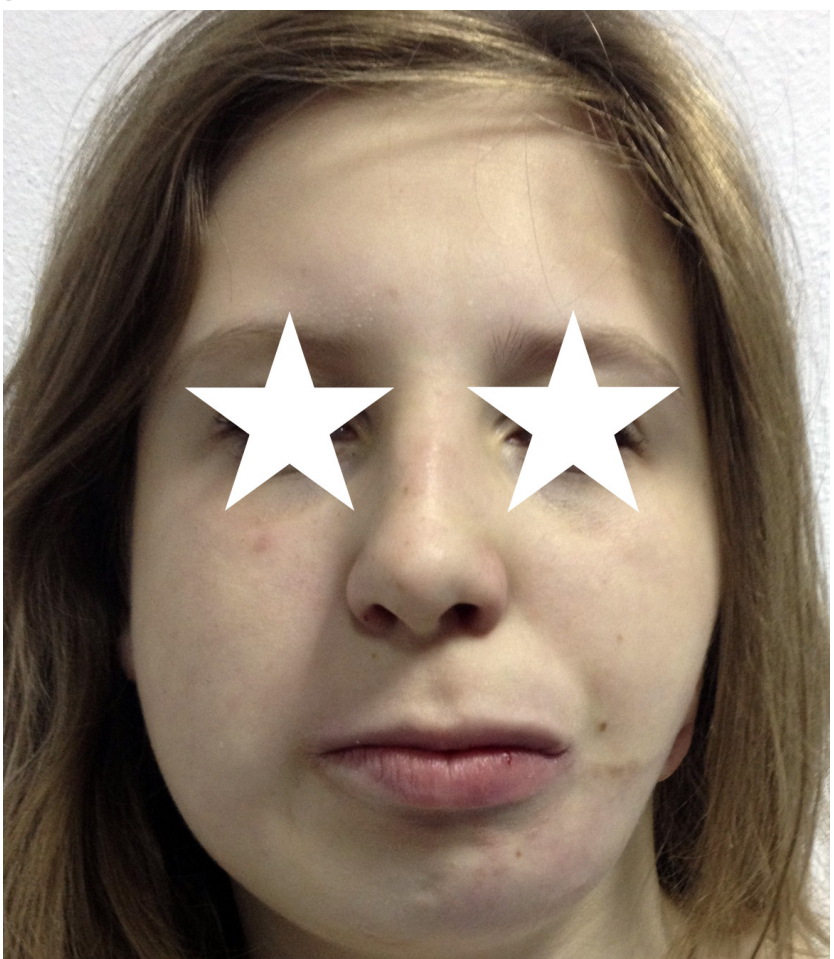

E

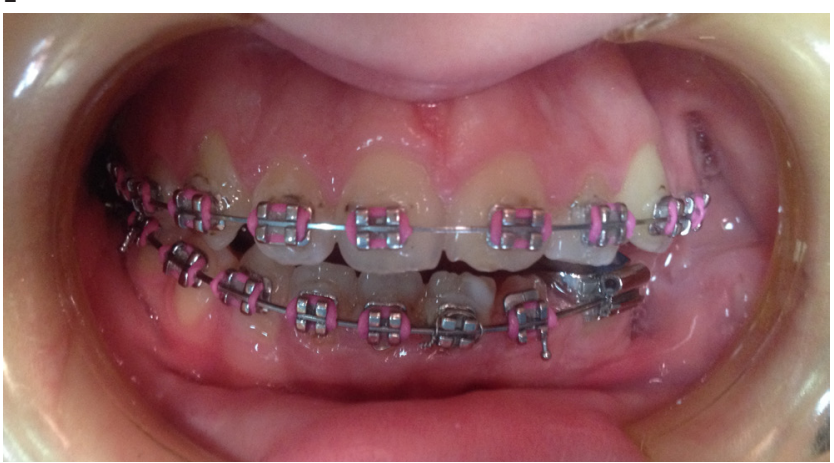

Much more difficult problems are related to the treatment of asymmetry caused by temporomandibular joint ankylosis (TMJA), and especially to deformities that occur in early childhood as a result of trauma and perinatal infections. ${ }^{14,38}$ Immobilisation of the mandible and destruction of its growth centres contribute to severe mandibular hypoplasia with well-known respiratory problems, malnutrition, and a predisposition to life-threatening infections.

Deformity and facial asymmetry applies not only to unilateral forms, but also occurs in bilateral ankylosis, in which distortions are often asymmetrical.

TMJA treatment consists of 2 parts. The most important is a complete resection of ankylosis, which, in severe forms involving the base of the skull, is very difficult and dangerous. After gap arthroplasty, an even greater shortening of the mandibular ramus arises, which calls for spacers to also act as separators. Although the use of silicone blocks or other materials can improve facial symmetry
Fig. 7. Unilateral temporomandibular joint ankylosis (TMJA) before treatment (A); schematic representation of mandibular deformity, post-excision defect, and normal mandible restoration (B). The result of treatment with the use of costochodral graft and application of external distractor, according to our own method (C)

A

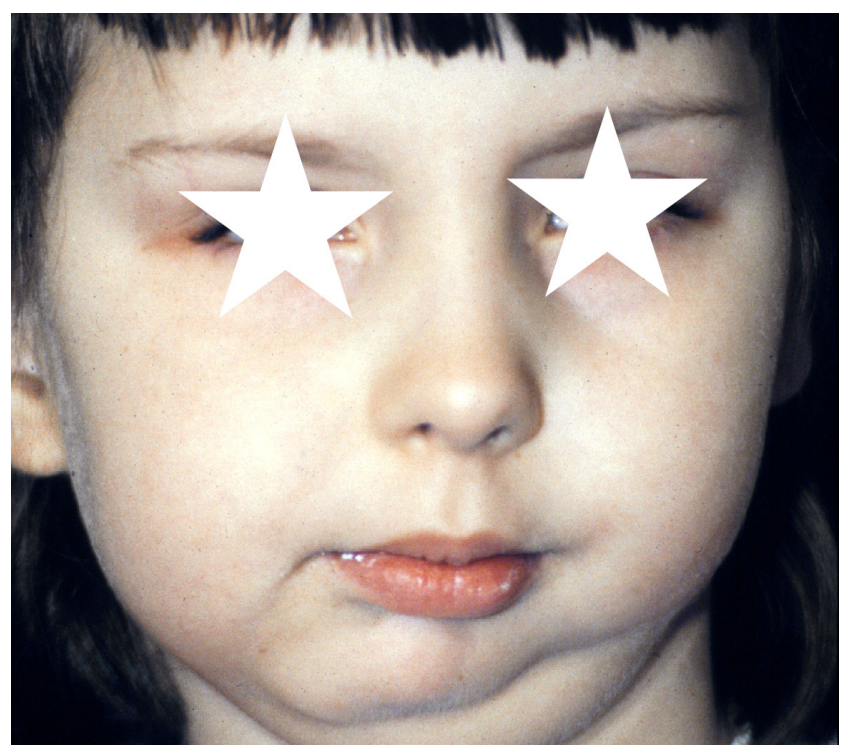

B
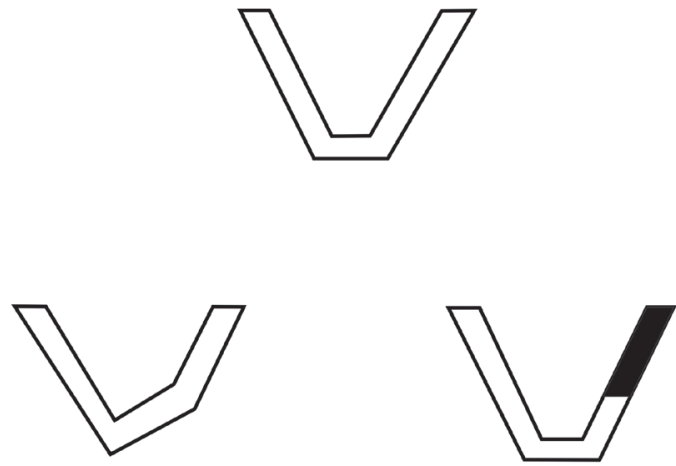

C

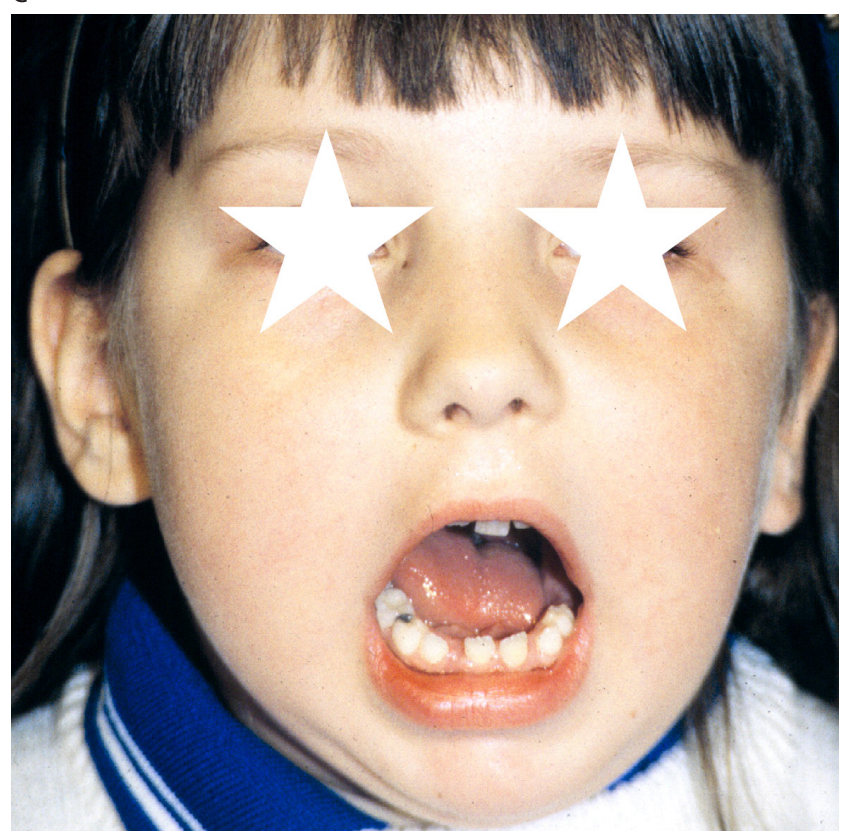

From: Kobus K. Atlas chirurgii plastycznej. Warszawa: Medsportpress; 2004 and Kobus K. Chirurgia i estetyka twarzy, Wrocław: ArsMedica, 2014. 
Fig. 8. An example of treatment for cosmetic reasons (without functional disorders); facial scoliosis before (A, B) and after bi-jaw osteotomy, rhinoplasty and chin advancement, without correction of moderate orbit dystopia (C, D)
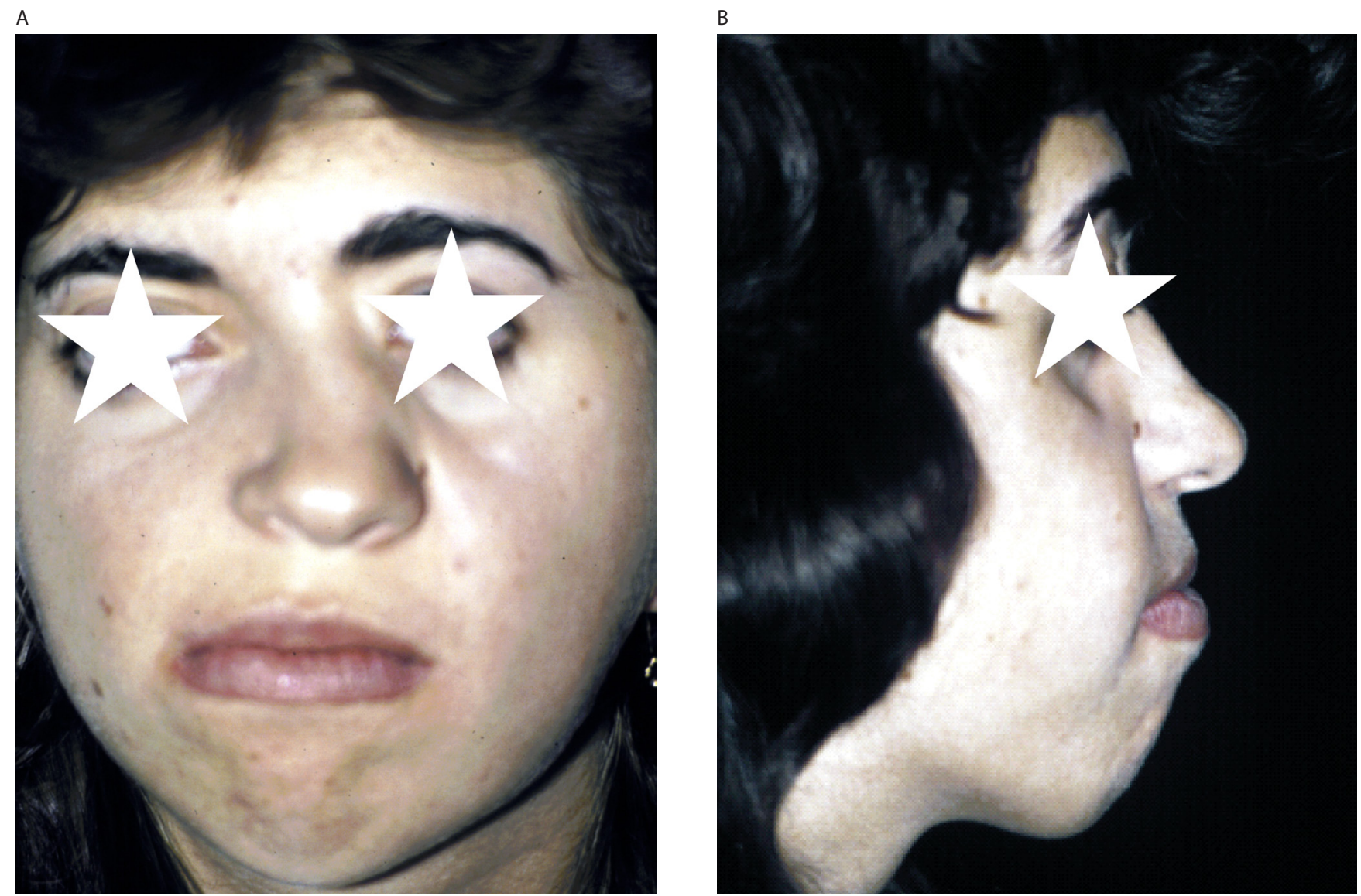

C

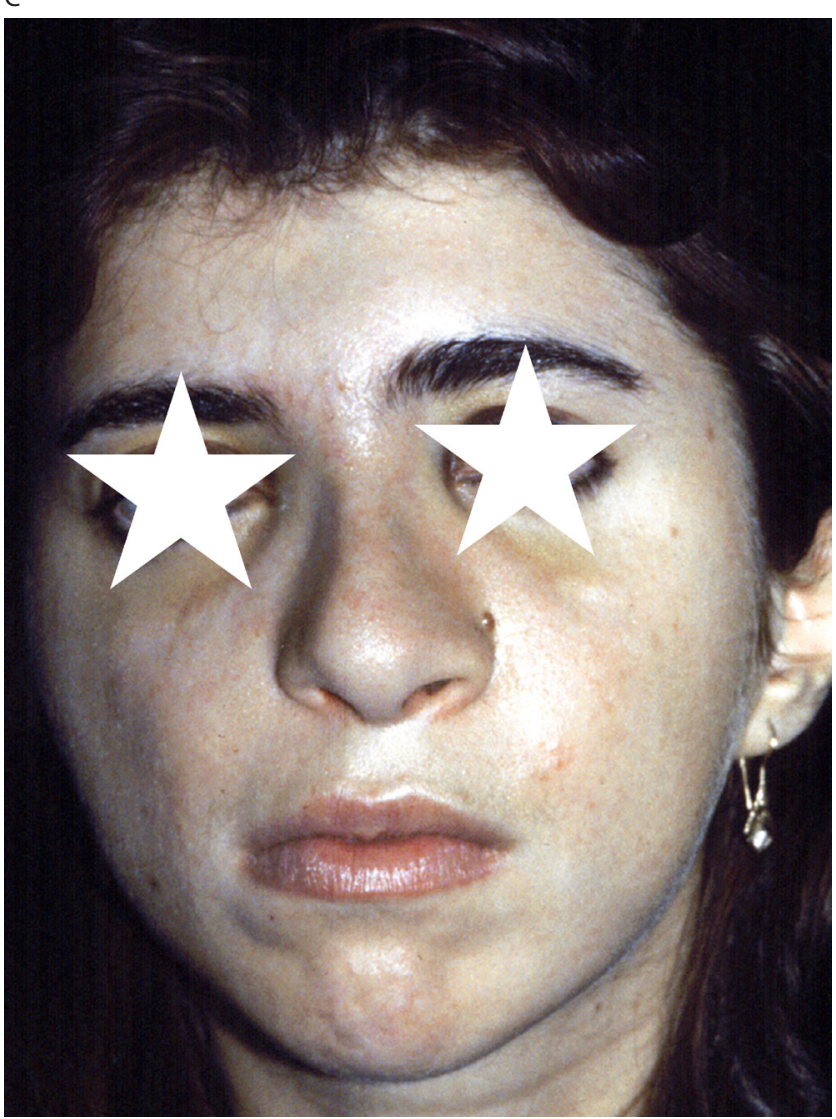

$\mathrm{D}$

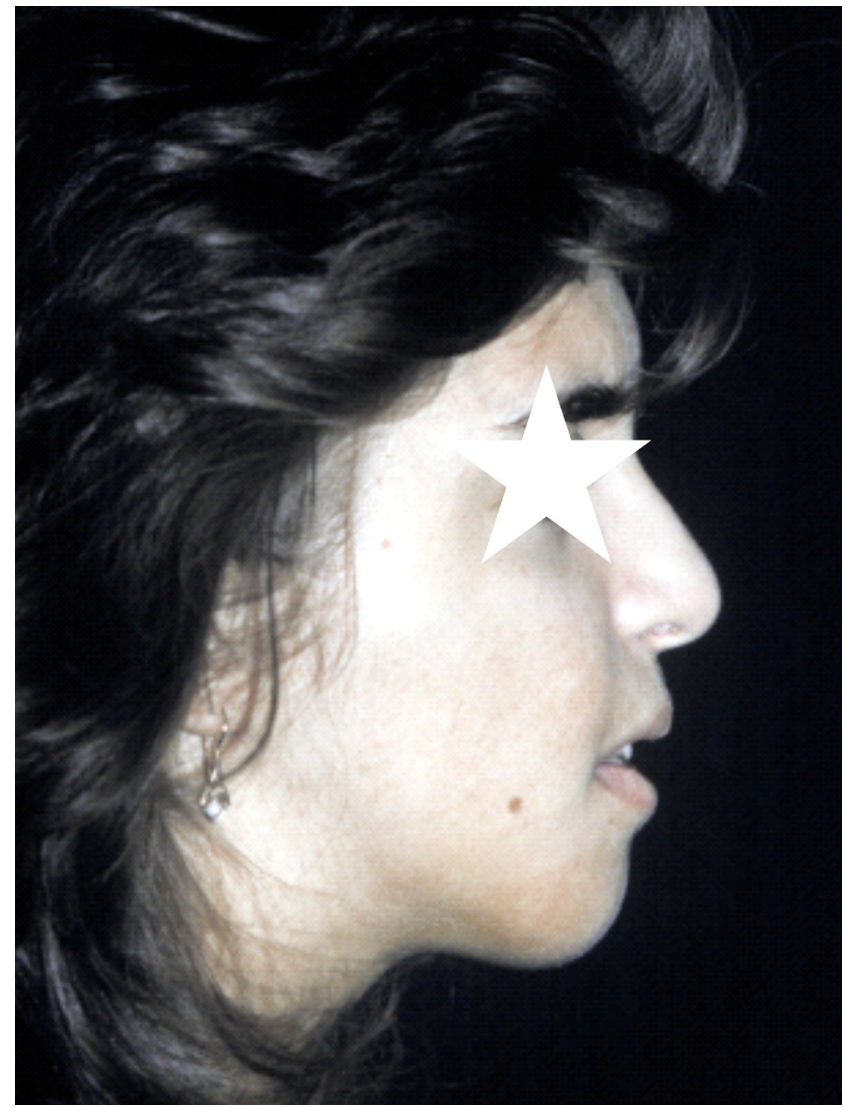

From: Kobus K. Atlas chirurgii plastycznej. Warszawa: Medsportpress; 2004 and Kobus K. Chirurgia i estetyka twarzy, Wrocław: ArsMedica, 2014. 
and prevent re-ankylosis, reconstruction of the missing part or mandibular distraction are considered more efficient. ${ }^{38,39}$

According to common belief, the use of costochondral grafts is a rather cumbersome procedure, because their healing require many weeks of immobilisation, which promotes the recurrence of ankylosis. In order to avoid these problems, the use of external distractors has been adopted (KK) to keep the jaw in the correct position, and to prevent the graft being crushed. ${ }^{14}$ Moreover, the full range of motion in one plane is secured, which, as demonstrated in our own material, does not affect the process of graft healing (Fig. 7).

Another, less cumbersome method is the use of procedure known as transport distraction. ${ }^{39}$ The operation is based on the upper-side portion of the mandibular ramus corticotomy, which after a period of latency is moved gradually upward until it makes contact with the articular fossa.

Reconstruction with the use of condylar or total TMJ prostheses is regarded to be a last resort for the treatment of the severest and recurrent ankyloses. Very rarely indeed, there can also be a need for downward transposition of the maxilla. In such cases, the above-mentioned TMJ reconstruction is combined with maxilla osteotomy or internal distraction, which makes operations much more difficult. ${ }^{40}$

In ankyloses, which are long-lasting despite TMJ reconstruction, complete facial symmetry is rarely achieved, and some imperfections can be noted. In children, restoration of mandibular mobility and functional stress impact makes self-correction of the involved anatomical structures possible, while in adults, modelling and refinement procedures are needed, such as a chin osteotomy or dermal grafts.

In all of the above deformities, an essential part of success depends on orthodontic treatment with the use of fixed appliances, because the formation of proper dental arches and the restoration of normal occlusion are of prime importance indeed. As the efficiency of contemporary orthodontics is impressive indeed, the only problem applies to the admittedly rare tendency toward excessive correction in patients with moderate maxillary hypoplasia and slanting position, which should probably be referred to surgical treatment.

\section{Final considerations}

Judging from the fragmentary review described above, facial asymmetries are characterised by a wide diversity. Some of them are primary in nature, and their management applies to the well-known rules established for the treatment of congenital malformations. Others occur as a result of diseases and a single or composed trauma such as, e.g., neoplastic eventerations with devastating orbital area irradiation.
The possibility and methods of treatment are determined by the location of affected tissues, the functional impairments, the duration of pathology, and its severity. A limitation in or poor quality of local tissues such as impaired blood supply, scarring, or bone sclerosis call for substitute distant flap transplantation, which a priori makes restitutio ad integrum impossible. Therefore, in severe asymmetries, fully satisfactory outcomes are uncommon.

The grounds for comprehensive and costly treatment are justified and accepted as a rule, but in less affluent countries some financial restrictions are not uncommon. ${ }^{41}$ It mostly applies to patients with debatable functional disorders, seeking a better appearance even if it demands extensive surgery (Fig. 8). As social security systems are discouraged due to the high costs of comprehensive treatment, the reluctance of hospital managers comes not only from underestimation of the costs, but is also related to expensive specialised equipment (such as surgical navigation) and, despite a lack of clear protocols, increasing formal requirements. Those surgeons who are willing and able to deal with these problems have only a sense of satisfaction mixed with a fear of the threat of consequences for failures and complications, even ones that were not committed. As their prevalence is immanently associated with complex surgical procedures, the "no excuse" rule, which is often applied by the authorities and mass media, discourages the treatment of wrongly classified quasi-cosmetic patients.

\section{References}

1. Thiesen G, Gribel BF, Freitas MP. Facial asymmetry: A current review. Dental Press J Orthod. 2015;20:110-125.

2. Cheong YW, Lo LJ. Facial asymmetry: Etiology, evaluation, and management. Chang Gung Med J. 2011;34:341-351.

3. Waite PD, Urban SD. Management of facial asymmetry. In: Miloro $\mathrm{M}$, ed. Peterson's principles of oral and maxillofacial surgery. $2^{\text {nd }}$ ed. Hamilton, Ontario: BC Decker Inc; 2004:1205-1219.

4. Ko EW, Huang CS, Chen YR. Characteristics and corrective outcome of face asymmetry by orthognatic surgery. J Oral Maxillofac Surg. 2009;67:2201-2209.

5. Bishara SE, Burkey PS, Kharouf JG. Dental and facial asymmetries: A review. Angle Orthod. 1994;64:89-98.

6. Severt TR, Proffit WR. The prevalence of facial asymmetry in the dentofacial deformities population at the University of North Carolina. Int J Adult Orthodon Ortognath Surg. 1997;12:171-176.

7. Chew MT. Soft and hard tissue changes after bimaxillary surgery in Chinese class III patients. Angle Orthod. 2005;75:959-963.

8. McCarthy JG, Schreiber J, Karp N, Thorne CH, Grayson BH. Lengthening of the human mandible by gradual distraction. Plast Reconstr Surg. 1992;89:1-8.

9. Kobus K, Pisulska-Otremba A, Kobus-Zaleśna K. Kortykotomia i dystrakcja kości twarzowo-czaszkowych. Pol Przegl Chir. 2002;74:933-940.

10. Ortiz-Monasterio F, Molina F, Andrade L, Rodriguez C, Sainz Arregui J. Simultaneous mandibular and maxillary distraction in hemifacial microsomia in adults: Avoiding occlusal disasters. Plast Reconstr Surg. 1997;100:852-861.

11. Ko EW, Hung KF Huang CS, Chen PK. Correction of facial asymmetry with multiplanar mandible distraction: A one-year follow-up study. Cleft Palate Craniofac J. 2004;41:5-12.

12. Kaufman MR, Miller TA, Huang $C$, et al. Autologous fat transfer for facial recontouring: Is the science behind the art? Plast Reconstr Surg. 2007;119:2287-2296. 
13. Guijarro-Martínez R, Miragall Alba L, Marqués Mateo M, Puche Torres M, Pascual Gil JV. Autologous fat transfer to the cranio-maxillofacial region: Updates and controversies. J Craniomaxillofac Surg. 2011;39:359-363.

14. Kobus K. Atlas chirurgii plastycznej. Warszawa: Medsportpress; 2004:101-112.

15. Siebert JW, Anson G, Longaker MT. Microsurgical correction of facial asymmetry in 60 consecutive cases. Plast Reconstr Surg. 1996;97:354-363.

16. Ji Y, Li T, Shamburger S, Jin J, Lineaweaver WC, Zhang F. Microsurgical anterolateral thigh fasciocutaneous flap for facial contour correction in patients with hemifacial microsomia. Microsurgery. 2002;22:34-38.

17. Tanna N, Broer PN, Roostaeian J, Bradley JP, Levine JP, Saadeeh PB Soft tissue correction of craniofacial microsomia and progressive hemifacial atrophy. J Craniofac Surg. 2012;23:2024-2027.

18. Agostini T, Spinelli G, Marino G, Parello R. Esthetic restoration in progressive hemifacial atrophy (Romberg disease): Structural fat grafting versus local/free flaps. J Craniofac Surg. 2014;25:783-787.

19. Vaienti L, Soresina M, Menozzi A. Parascapular free flap and fat grafts: Combined surgical methods in morphological restoration of hemifacial progressive atrophy. Plast Reconstr Surg. 2005;116:699-711.

20. Różyło TK, Różyło-Kalinowska I. Radiologia stomatologiczna. Warszawa: PZWL; 2008.

21. Yu CC, Wong FH, Lo LJ, Chen YR. Craniofacial deformity in patients with uncorrected congenital muscular torticollis: An assessement from three-dimentional computed tomography imaging. Plast Reconstr Surg. 2004;113:24-33.

22. Arnaud E, Marchac D, Renier D. Craniosynostosis and faciocraniosynostosis. Ann Chir Plast Esthet. 1997;42:443-480.

23. Lo LJ, Marsch JL, Pilgram TK, Vannier MW. Plagiocephaly: Differential diagnosis based on endocranial morphology. Plast Reconstr Surg. 1996;97:282-291.

24. Kobus K, Łątkowski I. Przedwczesne zarośnięcie szwów czasz kowych - wieloletnie doświadczenia w leczeniu 165 pacjentów. Pol Przegl Chir. 2005;77:335-353.

25. Stricker M, Gérard H, Moret C, Vigneron J, Malet T, Stricker C. Unusual facial clefts. Ann Chir Plast Esthet. 1997;42:401-441.

26. Kobus K. Operacje kostne w rozszczepach twarzy. Pol Przegl Chir. 1994;47:665-671.

27. Kobus K, Kobus-Zaleśna K. Timing of cleft lip and palate repair. Dev Period Med. 2014;18:9-83.

28. Semb G. A study of facial growth in patients with unilateral cleft lip and palate treated by the Oslo CLP Team. Cleft Palate Craniofac J. 1991;28:1-21.

29. Kobus K. Własne doświadczenia w leczeniu rozszczepów wargi, wyrostka zębodołowego i podniebienia. Own experience in the treatment of lip and palate clefts. Pol Przeg/ Chir. 2005;77:761-778.

30. Rychlik D, Wójcicki P. Osteoplastyka wyrostka zębodołowego w całkowitym jednostronnym i obustronnym rozszczepie wargi i podniebienia - badania prospektywne. Dental Med Probl. 2010:47:379-383.

31. Marchac D. Intracranial enlargement of the orbital cavity and palpebral remodeling for orbitopalpebral neurofibromatosis. Plast Reconstr Surg. 1984;73:534-543.

32. Kobus K, Licznerski A, Stępniewski J, Wiertel L, Charko W. The surgical treatment of vascular tumors of the face. J Maxillofac Surg. 1982;10:99-112.

33. Jackson IT, Carreño R, Potparic Z, Hussain K. Hemangiomas, vascular malformations, and lymphovenous malformations: Classification and methods of treatment. Plast Reconstr Surg. 1993;91:1216-1230.

34. Kobus-Zaleśna K. Połowiczy niedorozwój czaszkowo-twarzowy. Ortod Współcz. 2003;5:103-113.

35. Pruzansky S. Not all dwarfed mandibles are alike. Birth Defects. 1969;1:120-127.

36. Kaban LB, Moses MH, Mulliken JB. Surgical correction of hemifacial microsomia in the growing child. Plast Reconstr Surg. 1988;82:9-19.

37. Munro IR, Phillips JH, Griffin G. Growth after construction of the temporomandibular joint in children with hemifacial microsomia. Cleft Palate J. 1989;26:303-311.

38. Gundlach KK. Ankylosis of the temporomandibular joint. J Craniomaxillofac Surg. 2010;38:122-130.
39. Stucki-Mc Cormick SU. Reconstruction of the mandibular condyle using transport distraction osteogenesis. J Craniofac Surg. 1997;8:48-52.

40. Movahed R, Teschke M, Wolford LM. Protocol for concomitant temporomandibular joint custom-fitted total joint reconstruction and orthognathic surgery utilizing computer-assisted surgical simulation. J Oral Maxillofac Surg. 2013;71:2123-2129.

41. Choi JY, Choi JP, Lee YK, Beak SH. Simultaneous correction of hardand soft-tissue facial asymmetry: Combination of orthognatic surgery and face lift using a resorbable fixation device. J Craniofac Surg. 2010;21:363-370. 